Article

\title{
The Global Dimension of Water Governance: Why the River Basin Approach Is No Longer Sufficient and Why Cooperative Action at Global Level Is Needed
}

\section{Arjen Y. Hoekstra}

Twente Water Centre, University of Twente, P.O. Box 217, 7500 AE Enschede, The Netherlands; E-Mail: a.y.hoekstra@utwente.nl; Tel.: +31-53-489-3880; Fax: +31-53-489-5377

Received: 8 November 2010; in revised form: 11 December 2010 / Accepted: 19 December 2010 / Published: 29 December 2010

\begin{abstract}
When water problems extend beyond the borders of local communities, the river basin is generally seen as the most appropriate unit for analysis, planning, and institutional arrangements. In this paper it is argued that addressing water problems at the river basin level is not always sufficient. Many of today's seemingly local water issues carry a (sub)continental or even global dimension, which urges for a governance approach that comprises institutional arrangements at a level beyond that of the river basin. This paper examines a number of arguments for the thesis that good water governance requires a global approach complementary to the river basin approach. Subsequently, it identifies four major issues to be addressed at global scale: Efficiency, equity, sustainability and security of water supply in a globalised world. Finally, the paper raises the question of what kind of institutional arrangements could be developed to cope with the global dimension of water issues. A few possible directions are explored, ranging from an international protocol on full-cost water pricing and a water label for water-intensive products to the implementation of water footprint quotas and the water-neutral concept.
\end{abstract}

Keywords: water governance; scales; globalization; climate change; virtual water trade; water footprint; sustainable development; geopolitics 


\section{Introduction}

Many water problems extend beyond the borders of local communities, often due to upstream-downstream linkages within catchments and river basins. It has therefore been widely acknowledged that - if necessary to move towards a higher spatial level — the river basin is the most appropriate unit for analysis, planning and institutional arrangements. In this paper it is argued that addressing water problems at the river basin level is not always sufficient. It is shown that a substantial part of today's water issues carries an intrinsically (sub)continental or even global dimension, which urges for a governance approach that comprises coordination and thus some form of institutional arrangements at a level above that of the river basin.

The paper is based on the premise that any water system is an inseparable part of the environmental system as a whole and that the societal and environmental systems are inextricably bound up with each other as well. There is plenty of evidence that use of and changes to water systems cannot be understood separately from land use [1-3], spatial planning [4-5], soil management [6], climate change [7], demographic developments [8], economic consumption and production [9], public health [10], environmental management [11,12], international trade [13], politics [14], development cooperation [15] and national security [16,17]. In line with this understanding, it is assumed that 'water governance' (the manner in which people deal with water) should be understood as an integral part of governance in a much broader sense. 'Governance' in its general sense refers to the processes and systems through which a society operates. It relates to the broad social system of governing, which includes, but is not restricted to, the narrower perspective of government as the main decision-making political entity. Governance refers to both formal and informal structures, procedures and processes. According to the Global Water Partnership, 'water governance' refers to the range of political, social, economic and administrative systems that are in place to develop and manage water resources, and the delivery of water services, at different levels of society [18]. The term 'water governance' is preferred here above the term 'water management' because the latter is mostly used in the traditional context of governments managing water systems, supply and demand, while we explicitly aim to take a broader perspective.

Achieving effective water governance demands a broad approach, which essentially means: Coordination with other forms of governance. 'External coordination' in the context of water governance is understood here as coordination with the broader set of processes and systems through which society operates. For effective water governance, it is not sufficient to question which instruments water managers have, or which arrangements water managers can make, to solve the water problems of today and the future. One should address the broader question of how societies as a whole can manage their water resources in a wise manner. This approach of 'good water governance' necessarily has a much broader perspective than that of the water manager. The relevance of 'external coordination' is taken as a starting point in this paper.

The central argument of the paper is that the relevance of external coordination for effective water governance brings with it the necessity of including coordination at higher spatial levels than that of the river basin. It will be argued that neglecting the global dimension of water governance would carry the risk that developments outside the domain of water governance could overrule and possibly even nullify the good intentions in the domain of water governance. 
In the next section, I examine a number of arguments for the thesis that good water governance requires a global approach complementary to the river basin approach. The third section identifies and discusses four major issues to be addressed at global scale: Efficiency, equity, sustainability and security of water supply in a globalized world. The fourth section includes an explorative analysis of possible global water governance arrangements. Explorative means in this case that it is not intended to be exhaustive and that identification of possible types of arrangements has priority over reviewing the political feasibility of the identified arrangements.

\section{Why the River Basin Approach Is No Longer Sufficient}

\subsection{The Growing Number of Inter-basin Water Transfer Projects}

Water scarcity has become so great in some parts of the world that policy makers no longer believe that it is economically unfeasible to transport water over large distances; witness the planned inter-basin water transfers for instance in China [19-24], India [25-27], Southern Africa [28,29] and Spain [30]. Although not implemented, plans have also been developed to ship water from Turkey to Israel. The practice of inter-basin water transfers is not recent, but the scale of current proposals in terms of volumes and transfer distance is greater than ever before. Currently there are 155 inter-basin water transfer schemes in the world, spanning 26 countries and with a total capacity of transferring 490 billion $\mathrm{m}^{3} / \mathrm{yr}$ [31]. Plans exist for another 60 schemes with a total capacity of 1,150 billion $\mathrm{m}^{3} / \mathrm{yr}$.

Apparently it is no longer obvious to various governments that water demand and supply have to match within the boundaries of a river basin. The idea has been established that regional water shortages such as in North China can be solved by artificial import of water from elsewhere, over large distances and crossing the classical watersheds. It seems that large-scale inter-basin water transfer schemes increasingly become technically possible and economically and politically feasible, but the nature of large-scale water transfers has huge impacts on the natural environments and societies of both the supplying and the receiving regions. As a result, the actual political question is no longer limited to how water shortages in one particular basin can be solved but how different regions, covering more than one basin, can cooperate in development. The question is no longer a water-supply question alone and no longer a question at the level of one river basin. The recognition of inter-basin water transfer as a possibility implies that the scope of water resources planning and management necessarily broadens up. The region that receives water through an inter-basin water transfer supposedly profits from the water supply, but the supplying region has to be compensated in one way or another, be it in the form of money, energy, food or something else. The scope of water management thus broadens up, through the increased spatial scale, but also through the broadening of the problem definition.

\subsection{The Growing Importance of Multinationals in the Water Sector}

The past decade has shown a growing presence of transnational corporations in the drinking water sector. An increasing number of municipalities are served by private companies that often run water services across the globe. At the same time, production of bottled water is steadily increasing [32]. Barlow and Clarke [33] have argued that drinking water is gradually turning from a public resource 
into a commercial commodity with global players. Petrella [34] calls this the 'commodification of water'. Questions, such as whether water should be treated as a resource or a commodity, and whether water should come under the regulations of the World Trade Organization or not, are nowadays hot topics at international water forums.

As a result of the process of privatization in the water supply sector during the past two decades in several countries, water supplies have fallen to an increasing degree into the hands of large multinationals. Made possible and stimulated by the loan practice of the World Bank, 70\% of the private water supply systems in the world is currently owned by the three largest water companies-Veolia, Suez and RWE Thames Water. Some consider this an obvious development, which will ensure that through enlargement of scale water supplies will become more efficient and that the standards of water supplies in the developing countries will be pushed up towards levels that are more common in the north. Others instead see a frightening picture, in which water, a basic need for everyone [35], becomes a tradable commodity that can be obtained only by those who can afford to pay [33]. Shiva [36] further argues that in many cases the privatization of water leads to a situation in which companies profit from overexploitation of water resources, because scarce water resources can still be freely obtained and exploited without covering the cost of negative externalities.

\subsection{The Effect of Global Climate Change on Local Water Conditions}

Local precipitation and thus local water availability and peak flows depend on local climate conditions, which in turn are influenced by global climate conditions [7,37]. Evidence is available that humans have played, and will continue to play, a role in changing climate by contributing to the emission of greenhouse gases [38] and aerosols [39] and through changing land use [40-42]. Whereas the effects of land use changes are often still limited to the climate at (sub)continental level [43], the effects of aerosols and greenhouse gases are very much global [44]. Good governance of local water systems can thus be hampered or impaired by mechanisms that go beyond the governance domain of water managers who operate at the local, national or river basin level. They can use their power to influence water use, but not land or energy use, to say nothing about the fact that their power does not surpass the scale of the river basin. Arrangements for good water governance would include institutions that coordinate efforts to manage water with efforts to manage the land in the wider surroundings as well as the globe's energy resources. Overlooking this external component of water governance could in some cases possibly result in the extreme situation that the good work of local water managers is completely nullified by external, global developments. Consider the case of the Dutch river delta, where the work of water managers in the coming decades will be continuously challenged by sea level rise, changing local climate and growing peak river discharges (all three due to global climate change) and subsidence of the land (due to land use and gas extraction) [45-47]. Similarly, dedicated water demand strategies in the Mediterranean will have little effect in closing the gap between demand and supply if gains in reducing water demand are accompanied by climate change-driven reductions in water availability. 


\subsection{The Effect of the Global Economy on Local Water Pollution}

Overexploitation of the soil in some places, excessive use of fertilizers in others, long-distance transfers of food and animal feed and concentrated disposal of nutrient-rich wastes in densely populated areas of the world cause disturbances in the natural cycles of nutrients, such as nitrogen and phosphorus [48]. This has already led, and will further lead, to depletion of the soil in some areas [49-50] and eutrophication of water elsewhere [51,52]. For example, the surplus of nutrients in the Netherlands is partially related to deforestation, erosion and soil degradation in those areas of the world that export food and feed to the Netherlands; for example in Brazil from where a lot of soybeans for the Dutch pigs and chickens are imported. This implies that the nutrient surplus in the Netherlands is not an issue that can simply be handled by the Dutch in isolation. Dutch water pollution is part of the global economy.

The disturbance of nutrient cycles is not the only mechanism through which the global economy influences the quality of water resources worldwide. Meybeck and Helmer [53] and Meybeck [54] show how other substances are also dispersed into the global environment and change the quality of the world's rivers. Nriagu and Pacyna [55] set out the specific impacts of the use of trace metals in the global economy on the world's water resources. The regular publication of new reports on global pollution shows that this phenomenon in itself is no longer news; what is now gradually being uncovered and therefore relatively new is the fact that pollution is not simply 'global' because pollution is so 'widespread', but that it is interlinked with how the global economy works and is therefore a true global problem. Water pollution is intertwined with the global economic system to such an extent that it cannot be dealt with independently from that global economy. Indeed, pollution can be tackled by end-of-pipe measures at or near the location of the pollution, but a more cause-oriented approach would be restructuring the global economy, with the aim of the closure of element cycles. Making adjustments to the organization of the global economy would obviously require international coordination.

\subsection{The Effect of the Global Economy on Local Water Use and Scarcity}

Export of water-intensive commodities implies that the domestic water resources are more intensively used than they would have been in the case without such export. As a result, the pressure on, and the scarcity of, the domestic water resources will be increased. In reverse, countries that import water-intensive commodities relieve the pressure on their domestic water resources.

\subsubsection{Nations seeking domestic water saving through virtual water import}

The virtual water content of a product is the volume of water used to produce it, measured at the place where it was actually produced. The adjective 'virtual' refers to the fact that most of the water used in the production is in the end not contained within the product. The real water content of products is generally negligible if compared to the virtual water content. The (global average) virtual water content of wheat for instance is in the order of 1,500-1,600 $\mathrm{m}^{3} / \mathrm{ton}$, while the real water content is obviously less than $1 \mathrm{~m}^{3} /$ ton [56,57]. While transfer of real water over long distances is very costly and therefore generally not economically feasible, transfer of water in virtual form can be an efficient 
way of obtaining water-intensive products in places where water is very scarce. The concept of 'virtual water import' as a means of releasing the pressure on domestic water resources was introduced by Allan [14,58] when he studied the water scarcity situation of the Middle East. Virtual water import could be regarded as an alternative water source, alongside endogenous water sources. Imported virtual water has therefore also been called 'exogenous water' or 'embedded water' [59].

An increasing number of water-short countries, most particularly in North Africa and the Middle East, seek to preserve their domestic water resources through the import of water in virtual form, by importing water-intensive commodities (relatively high water input per dollar of product) and exporting commodities that are less water-intensive. Jordan, as an example, imports about five to seven billion cubic meters of virtual water per year [60,61], which is much more than the one billion cubic meter of water annually withdrawn from its domestic water sources. Even Egypt, with water self-sufficiency high on the political agenda and with a total water withdrawal within the country of 65 billion cubic meters per year, still has an estimated annual net virtual water import of 10 to 20 billion cubic meters [61,62].

Further removal of trade barriers, as foreseen for the future, particularly in the case of agricultural commodities, will facilitate increased international trade in water-intensive commodities. Virtual water import as a tool to reduce the pressure on domestic water resources can thus become attractive to an increasing number of water-short nations [63]. Disregarding political objectives that might work in a different direction, according to international trade theory the people of a nation will seek profit by trading products that are produced with resources that are relatively abundantly available within their country for products that need resources that are relatively scarce. This theory, known as the theory of comparative advantage, has been proposed as a useful analytical tool to study the economic attractiveness of virtual water import for nations that have comparatively little water and of virtual water export for nations that have comparatively abundant water resources [64].

During the past few years various global studies have been carried out to quantify the actual virtual water flows between nations: Hoekstra and Hung [65,66], Zimmer and Renault [62], Oki and Kanae [67], Chapagain and Hoekstra [61,68] and De Fraiture et al. [69]. All studies show that North and South America, Australia, most of Asia and Central Africa, have a net export of virtual water. The reverse, a net import of virtual water, can be found in Europe, Japan, North and Southern Africa, the Middle East, Mexico and Indonesia. Obviously, the import of virtual water in, for instance, Europe should be understood in a different context than the import of virtual water in North Africa and the Middle East. In the latter case, as has been demonstrated by Yang et al. [70], the virtual water import can be explained - at least partially - by the actual water scarcity situation in the countries of this region. The water availability in most of the countries in North Africa and the Middle East falls below a threshold of about $1,500-2,000 \mathrm{~m}^{3} / \mathrm{yr}$ per capita, below which net cereal import grows exponentially with decreasing water availability per person. It is not suggested here that all countries with a net import of water in virtual form do this because they intend to save domestic water resources. By importing virtual water they will indeed save domestic water resources, but this does not imply that the idea of water saving was necessarily the main driving force behind the virtual water imports. International trade in agricultural commodities depends on many more factors than water, such as availability of land, labor, knowledge and capital, the impossibility to grow certain crops or crop varieties in certain places, competitiveness (comparative advantage) in certain types of production, 
domestic subsidies, export subsidies and import taxes. As a consequence, international virtual water trade can in most cases not at all, or only partly, be explained on the basis of relative water abundance or shortage [69].

As shown in Table 1, the (intended or unintended) national water saving as a result of international trade in agricultural products can be substantial. In Algeria, water use would triple if the Algerians had to produce all imported products domestically.

Table 1. Examples of nations with net water saving as a result of international trade in agricultural products (Period 1997-2001).

\begin{tabular}{|c|c|c|c|c|c|}
\hline Country & $\begin{array}{c}\text { Total } \\
\text { consumption of } \\
\text { domestic water } \\
\text { resources in the } \\
\text { agricultural } \\
\text { sector } \\
\left(10^{9} \mathrm{~m}^{3} / \mathrm{yr}\right) \\
\end{array}$ & $\begin{array}{l}\text { Water saving as a } \\
\text { result of import of } \\
\text { agricultural } \\
\text { products }{ }^{2} \\
\left(10^{9} \mathrm{~m}^{3} / \mathrm{yr}\right)\end{array}$ & $\begin{array}{l}\text { Water loss as a } \\
\text { result of export of } \\
\text { agricultural } \\
\text { products }{ }^{2} \\
\left(10^{9} \mathrm{~m}^{3} / \mathrm{yr}\right)\end{array}$ & $\begin{array}{l}\text { Net water } \\
\text { saving due to } \\
\text { trade in } \\
\text { agricultural } \\
\text { products }{ }^{2} \\
\left(10^{9} \mathrm{~m}^{3} / \mathrm{yr}\right)\end{array}$ & $\begin{array}{c}\text { Ratio of } \\
\text { water saving } \\
\text { to water use }\end{array}$ \\
\hline China & 733 & 79 & 23 & 56 & $8 \%$ \\
\hline Mexico & 94 & 83 & 18 & 65 & $69 \%$ \\
\hline Morocco & 37 & 29 & 1.6 & 27 & $73 \%$ \\
\hline Italy & 60 & 87 & 28 & 59 & $98 \%$ \\
\hline Algeria & 23 & 46 & 0.5 & 45 & $196 \%$ \\
\hline Japan & 21 & 96 & 1.9 & 94 & $448 \%$ \\
\hline
\end{tabular}

${ }^{1}$ Source: [61].

${ }^{2}$ Source: [71]. Agricultural products include both crop and livestock products.

The studies on international virtual water trade show that water should be regarded as a global resource (demand and supply match at global level), rather than as a river basin resource (demand and supply match within the basin). Effective governance of the world's water resources will require some type of coordination of the global 'water market'. Coordination could refer for example to agreements on area-specific 'sustainable levels' of water consumption and agreements on water pricing structures.

\subsubsection{Nations externalizing their water footprints}

The water footprint of an individual or community is defined as the total volume of freshwater that is used to produce the goods and services consumed by the individual or community. The water footprint of a nation does not only show water use within the country considered, but also water use outside the country borders $[59,72]$. The water footprint of the Dutch community, for example, also refers to the use of water for cotton production in China and the water use for producing citrus fruits in Spain, insofar these commodities are exported to and consumed within the Netherlands [73]. Given the increase in international trade flows, the water footprints of people are increasingly externalized to other parts of the world. Consumers do generally not pay for the negative effects of their water footprints, because water supply is mostly heavily under-priced and also the negative effects of pollution are not taken into account in the price of the products [74]. Local water problems are thus strongly related to cheap consumption elsewhere, where 'cheap' refers to the fact that prices of 
water-intensive consumer goods generally include neither a water scarcity rent nor externalities that occur during production.

Global water use, including both green and blue water, is estimated to be 7,450 billion $\mathrm{m}^{3} / \mathrm{yr}$. The global volume of virtual water flows relating to the international trade in commodities is 1,625 billion

$\mathrm{m}^{3} / \mathrm{yr}$, of which 1,200 billion $\mathrm{m}^{3} / \mathrm{yr}$ refers to the export of home-made products; the remainder concerns re-exports of imported goods (in the same form as imported or in processed form) [59,72]. From these figures it follows that $(1,200 / 7,450=) 16 \%$ of global water use is not for producing domestically-consumed products, but for products for export. Assuming that, on average, agricultural production for export does not significantly cause more or fewer water-related problems (such as water depletion or pollution) than production for domestic consumption, this means that one-sixth of the water problems in the world can be traced back to production for export.

The physical distance between production and consumption and the fact that much of the consumer information on product origin and production circumstances is generally at best limited to information about country of origin and some data on the main ingredients, mean that there is a disconnection between consumption decisions and detrimental impacts of production. Consumption can only be reconnected with the effects of production through a global approach. Local or national measures to include externalities and a water scarcity rent in water-intensive products will not work satisfactorily, because such local products run the risk of becoming too expensive in the global market, which is dominated by others who have not yet taken such measures. In debates about the subject over the past few years, the author of this paper found that different views exist on the usefulness of uncovering the link between consumers and the effects of production, in this case the effects on the water systems in the production areas. Economists in particular appear not to recognize the usefulness of such an exercise. In fact, an anonymous reviewer of one of my manuscripts wrote: 'It is misleading to suggest that consumers of one nation are responsible for depleting resources in another via the mechanism of voluntary international trade.' In my view, however, both consumers and producers have a connection with, and bear at least partial responsibility for, problems caused by production. How to divide the responsibility over consumers and producers is an issue of ongoing debate [104,105]. When the consumption of a certain good in one area is related to a problem of water depletion or pollution in another area, as for instance in the case of European cotton consumers and the desiccation of the Aral Sea [75-77], this is an interesting starting point for an analysis of responsibilities and mechanisms that could possibly mitigate the environmental problem. The fact that trade is voluntary - and thus always beneficial for both trading partners according to economists-does not remove responsibilities from consumers and producers. The fact that trade is increasingly becoming a global issue means that mitigating the effects of production on water depletion and pollution also increasingly carries a global dimension.

\section{The Major Issues to Be Addressed at Global Scale}

\subsection{Global Water Use Efficiency}

The increasing demand for freshwater and the limited possibilities of raising supply urge for a greater efficiency in water use, that is: produce the same volume of goods and services with less water. 
Fortunately there are ample opportunities to increase water use efficiency. As pointed out by Hoekstra and Hung [66], greater water use efficiency can be achieved at three different levels: The local, basin and global levels.

At local level, that of the consumer, water use efficiency can be improved by: Charging prices based on full marginal cost [78]; stimulating water-saving techniques in farming such as water recycling, drip irrigation and the use of drought-resistant crop varieties [79,80]; promoting the use of water-saving appliances in industries and households; and creating awareness among water users of the possible detrimental impacts of water use [81]. In irrigation, the largest water-using sector in the world, water losses between water withdrawal and actual water uptake by the plant are very high: $76 \%$ of the water withdrawn in Latin America does not reach the plant, 68\% in Sub-Saharan Africa, 66\% in East Asia, 60\% in the Near East and North Africa and 56\% in South Asia [82]. Reducing those water losses would lessen the water requirement without reducing the water availability for the plant and thus without affecting crop yield. At the catchment or river basin level, water use efficiency can be enhanced by re-allocating water to those purposes with the highest marginal benefits [83], which can imply the re-allocation of water from the agricultural sector to the domestic or industrial sectors or the re-allocation of water from water-inefficient crops to more efficient crop types or varieties. Finally, at the global level, water use efficiency can be increased if nations use their comparative advantage or disadvantage in terms of water availability to encourage or discourage the use of domestic water resources for producing export commodities (respectively stimulate export or import of virtual water). Virtual water trade between nations - provided that trade goes in the right direction (from places with high, to places with low, water productivity) — can thus be a means of increasing the efficiency of water use in the world [67,71].

Whereas much research effort has been dedicated to study water use efficiency at the local and river basin levels (sometimes respectively called productive and allocative efficiency), few efforts have been made to analyze water use efficiency at global level. Nevertheless, there is sufficient evidence now that current global trade patterns result in global water saving, because much of the trade in water-intensive commodities takes place from countries with high water productivity (high value per unit of product) to countries with low water productivity. Thus far, four independent studies have been carried out to estimate the actual global water saving as a result of international trade. In the first study, Oki and Kanae [67] estimated that the current global water saving as a result of international trade in rice, wheat, soybean, maize, barley, chicken, pork and beef is 455 billion $\mathrm{m}^{3} / \mathrm{yr}$ in total. According to their study, the exporting countries use 683 billion $\mathrm{m}^{3} / \mathrm{yr}$, while the importing countries would have required 1,138 billion $\mathrm{m}^{3} / \mathrm{yr}$ if they had produced the imported products domestically. The difference is the global water saving. Oki and Kanae [67] accounted for the differences in yields in different countries, but assumed a constant global average crop water requirement throughout the world $(15 \mathrm{~mm} /$ day for rice and $4 \mathrm{~mm} /$ day for maize, wheat and barley). Thus the climatic factor, which plays an important role in the water requirement of a crop, was neglected. A second study, which takes climatic differences into account, is De Fraiture et al. [69], who estimated that international cereal trade in 1995 reduced global water use at crop level by 164 billion $\mathrm{m}^{3} / \mathrm{yr}$ and irrigation water depletion by 112 billion $\mathrm{m}^{3} / \mathrm{yr}$. In a third study, Chapagain et al. [71] took a more comprehensive approach and looked at the global water saving as a result of international trade in all agricultural products, including both crop and livestock products. For the period 1997-2001, they estimate the global water saving at 
352 billion $\mathrm{m}^{3} / \mathrm{yr}$, of which $63 \%$ related to international trade in cereals and cereal products, $19 \%$ to oil crops, $13 \%$ to livestock products and 5\% to pulses and other crops. Finally, Yang et al. [84] calculated a global water saving of 337 billion $\mathrm{m}^{3} / \mathrm{yr}$, relating to international trade in the most important crops. Due to differences in period and scope, the results of the studies mentioned cannot easily be compared, but they all confirm that the global water saving as a result of international trade can be substantial when compared with the total water use in agriculture. According to Chapagain et al. [71], the global water saving through trade in agricultural products is equivalent to $6 \%$ of the global volume of water used for agricultural production.

Although it is clear that global trade and water use efficiency are connected issues, there is no international agency that has ever included this connection in either trade policy or water policy considerations. The growing scarcity of freshwater in the world and the fact that water could possibly be saved by producing water-intensive commodities in places where water is comparatively abundant and trading them to places where it is not, demand international research and policy coordination in this field.

\subsection{Fairness and Sustainability of Water Use}

Some people around the world have comparatively high water footprints, which raises the question of whether this is fair and sustainable. Under current production conditions it would be impossible for all world citizens to develop a water footprint of the same size as the present water footprint of the average U.S. citizen. People in the U.S. have, on average, the largest water footprint per capita in the world, viz. 2,480 $\mathrm{m}^{3} / \mathrm{yr}$. China has an average water footprint of $700 \mathrm{~m}^{3} / \mathrm{yr}$ per capita, while the world average is $1,240 \mathrm{~m}^{3} / \mathrm{yr}[59,72]$. The issues of fairness and sustainability become very obvious in this imaginary growth scenario, but both are already relevant today.

Currently, about one billion people do not have 'sustainable access to an improved water source' [85], while others water their gardens, wash their cars, fill their swimming pools and enjoy the availability of water for many other luxury purposes. In addition, many people consume a lot of meat, which significantly enlarges their water footprint. The average meat consumption in the U.S. for instance is $120 \mathrm{~kg} / \mathrm{yr}$, more than three times the world average. This partially explains the fact that the average American citizen has the highest water footprint in the world. The water used to produce the feed for the animals that provide the meat for the rich cannot be used for other purposes, for example, to fulfill more basic needs of people who cannot afford to pay. The answer to the question of whether the current distribution of water footprints is fair is a political one and, furthermore, a global one. Redistribution of welfare among individuals is normally done within the borders of the nation state, but since the distribution of water and water-intensive products is very uneven across the globe, the redistributive question becomes a global one as well. The normative question at global level is whether wealthy water-rich nations should play a role in supporting developing water-poor nations, for instance by helping them to efficiently and sustainably use their scarce water resources.

What is a 'sustainable water footprint', given the seven billion inhabitants of the earth and the fact that the total water availability in the world is limited? The current global water footprint is 7,450 billion $\mathrm{m}^{3} / \mathrm{yr}[59,72]$, which in many places obviously leads to unsustainable conditions, as witnessed by the reported cases of water depletion and pollution [86-88]. Although the annual volume 
of precipitation over land is roughly known, it is very difficult to give a global figure for the maximum 'sustainable water footprint' as an upper limit to global water use. There are various reasons for this. One is that not all precipitation can be used productively, because its fall is unevenly spread in time and space, so that there are places and times that the water will inevitably flow to the oceans. According to Postel et al. [11] about $20 \%$ of total runoff forms remote flows that cannot be appropriated and 50\% forms uncaptured floodwater, so that only $30 \%$ of runoff remains for use. Although research in this direction has been done, it is not yet clearly established which fraction of this remaining flow should remain untouched in order to fulfill the environmental flow requirements $[12,89,90]$. It has also not been established what fraction of the total evapotranspiration on land may be counted as potentially productive. Finally, what we would count as the maximum 'sustainable water footprint' at global level depends on what assumptions would be made with respect to the level of technology. One could take water productivities as they are in practice at present (which differ from location to location), or one could work with the potential water productivities based on existing technology. The latter would lead to a more optimistic figure than the former, but also a less realistic one. So far no estimates of the world's maximum 'sustainable water footprint' have been made, but a general feeling exists that if it has not passed it already, the current global water footprint will not be far below the maximum sustainable value, witness the widely promoted need for water demand management and water use efficiency improvements [11,79,86-88]. This brings us back to the issue of fairness, because is it fair if some people use more than an equitable share of the maximum global volume of annually available water resources? The average person in North America and Southern Europe certainly does.

\subsection{Water Security: Water as a Geopolitical Resource}

Nations can be 'water dependent' in two different ways. They can be dependent on water that flows in from neighboring countries and they can be dependent on virtual water import. The first type of water dependency follows from the ratio of external to total renewable water resources of a country. FAO [91] defines the 'external renewable water resources' of a country as that part of the country's renewable water resources which is not generated in the country. It includes inflows from upstream countries (groundwater and surface water) and part of the water of border lakes or rivers. A difference is made between the 'natural' and the 'actual' external renewable water resources. The first term refers to the natural incoming flow originating outside the country; the actual external resources are possibly less than the natural external resources, because in this case upstream water abstractions are subtracted, as are water flows reserved for upstream and downstream countries through formal or informal agreements or treaties. The 'internal renewable water resources' of a country concern the average annual flow of rivers and recharge of aquifers generated by endogenous precipitation. The total renewable water resources of a country are the sum of internal and external renewable water resources. Table 2 shows the 'external water resources dependency' for a number of selected downstream countries. For a country like Egypt the dependency is extremely high, because the country receives hardly any precipitation and thus mostly depends on the inflowing Nile water. Similarly, but to a lesser extent, Pakistan strongly depends on the water of the Indus, Cambodia on the water of the Mekong and Iraq on the Tigris and Euphrates. In all these cases water is an important geopolitical resource, 
affecting power relations between the countries that share a common river basin. In a country like the Netherlands external water resources dependency is high but less important, because water is less scarce than in the previous cases. Nevertheless, here too there is a dependency, since activities within the upstream countries definitely affect downstream low flows, peak flows and water quality.

Table 2. Dependency on incoming river flows for some selected countries.

\begin{tabular}{|c|c|c|c|}
\hline Country & $\begin{array}{l}\text { Internal renewable water } \\
\text { resources }{ }^{1}\left(10^{9} \mathrm{~m}^{3} / \mathrm{yr}\right)\end{array}$ & $\begin{array}{l}\text { External (actual) renewable } \\
\text { water resources }{ }^{1}\left(10^{9} \mathrm{~m}^{3} / \mathrm{yr}\right)\end{array}$ & $\begin{array}{l}\text { External water resources } \\
\text { dependency }{ }^{2}(\%)\end{array}$ \\
\hline Iraq & 35 & 40 & 53 \\
\hline Cambodia & 121 & 356 & 75 \\
\hline Pakistan & 52 & 170 & 77 \\
\hline Netherlands & 1.1 & 80 & 88 \\
\hline Egypt & 1.8 & 56.5 & 97 \\
\hline
\end{tabular}

${ }^{1}$ Source: [91].

${ }^{2}$ Defined as the ratio of the external to the total renewable water resources.

The political relevance of 'external water resources dependency' of nations makes water a regional geopolitical resource in some river basins. The other type of water dependency, virtual water import dependency, makes water a global geopolitical resource. The fundamental reason is the combination of increasing scarcity of water, its unique character that prevents substitution and its uneven distribution throughout the world. Where water-abundant regions did not fully exploit their potential in the past, they now increasingly do so by exporting water in virtual form or even in real form. The other side of the coin is the increasing dependency of water-scarce nations on the supply of food or water, which can be exploited politically by those nations that control the water.

From a water resources point of view one might expect a positive relationship between water scarcity and virtual water import dependency, particularly in the ranges of great water scarcity. Water scarcity can be defined as the country's water footprint - the total volume of water needed to produce the goods and services consumed by the people in the country-divided by the country's total renewable water resources. Virtual water import dependency is defined as the ratio of the external water footprint of a country to its total water footprint. As Chapagain and Hoekstra [61] show, countries with a very high degree of water scarcity-e.g., Kuwait, Qatar, Saudi Arabia, Bahrain, Jordan, Israel, Oman, Lebanon and Malta —indeed have a very high virtual water import dependency $(>50 \%)$. The water footprints of these countries have largely been externalized. Jordan annually imports a virtual water quantity that is five times its own yearly renewable water resources. Although saving its domestic water resources, it makes Jordan heavily dependent on other nations, for instance the United States. Other water-scarce countries with high virtual water import dependency (25-50\%) are for instance Greece, Italy, Portugal, Spain, Algeria, Libya, Yemen and Mexico. Table 3 presents the data for a few selected countries. Even European countries that do not have an image of being water-scarce, such as the U.K., Belgium, the Netherlands, Germany, Switzerland and Denmark, have a high virtual water import dependency. In those cases where large virtual water imports go together with national water abundance, the import is obviously not related to water scarcity but must be explained by other factors. 
In most water-scarce countries the choice is either (over)exploitation of the domestic water resources in order to increase water self-sufficiency (the apparent strategy of Egypt) or virtual water import at the cost of becoming water dependent (Jordan). The two largest countries in the world, China and India, still have a very high degree of national water self-sufficiency (93\% and $98 \%$ respectively). However, the two countries have relatively low water footprints per capita (China $700 \mathrm{~m}^{3} / \mathrm{cap} / \mathrm{yr}$ and India $980 \mathrm{~m}^{3} / \mathrm{cap} / \mathrm{yr}$ ). If the consumption patterns in these countries change to that of the U.S. or some Western European countries, they will be facing a severe water scarcity in the future and will probably be unable to sustain their high degree of water self-sufficiency. A relevant question is how China and India are going to feed themselves in the future $[59,92]$. If they were to decide to partially obtain food security through food imports, this would put enormous demands on the land and water resources in the rest of the world.

Table 3. Virtual water import dependency of some selected countries. Period: 1997-2001.

\begin{tabular}{lcccc}
\hline Country & $\begin{array}{c}\text { Internal water } \\
\text { footprint }^{1} \\
\left(10^{9} \mathrm{~m}^{3} / \mathrm{yr}\right)\end{array}$ & $\begin{array}{c}\text { External water } \\
\text { footprint }^{1} \\
\left(10^{9} \mathrm{~m}^{3} / \mathrm{yr}\right)\end{array}$ & $\begin{array}{c}\text { Water } \\
\text { self-sufficiency }\end{array}$ & $\begin{array}{c}\text { Virtual water import }^{2} \\
\text { dependency }^{3}\end{array}$ \\
\hline Indonesia & 242 & 28 & 90 & $(\%)$ \\
Egypt & 56 & 13 & 81 & 10 \\
South Africa & 31 & 9 & 78 & 19 \\
Mexico & 98 & 42 & 70 & 22 \\
Spain & 60 & 34 & 64 & 30 \\
Italy & 66 & 69 & 49 & 36 \\
Germany & 60 & 67 & 47 & 51 \\
Japan & 52 & 94 & 36 & 53 \\
United Kingdom & 22 & 51 & 30 & 64 \\
Jordan & 1.7 & 4.6 & 27 & 70 \\
Netherlands & 4 & 16 & 18 & 73 \\
\hline Souce: & & & & 82 \\
\hline
\end{tabular}

${ }^{1}$ Source: [61].

${ }^{2}$ Defined as the ratio of the internal to the total water footprint.

${ }^{3}$ Defined as the ratio of the external to the total water footprint.

\section{An Explorative Analysis of Possible Arrangements to Address Global Water Issues}

The previous sections raise the question of what kind of institutional arrangements could be instituted to cope with the global dimension of water issues. A few potential directions are identified below in an explorative manner. I will not delve into the politics of pursuing the global arrangements put forward, but limit myself to drawing the contours of possible arrangements that address the global issues described above.

\subsection{An International Protocol on Water Pricing}

First of all, there is a need to arrive at a global agreement on water pricing structures that cover the full cost of water use, including investment costs, operational and maintenance costs, a water scarcity rent and the cost of negative externalities of water use. Such an agreement would need to include all water-using sectors, including agriculture. The need to have full cost pricing has been acknowledged 
since the Dublin Conference in 1992 [93]. A global ministerial forum to reach agreements on this does exist in the regular World Water Forums (Morocco 1997, The Hague 2000, Japan 2003, Mexico 2006, Turkey 2009), but these forums have not been used to take up the challenge of making international agreements on the implementation of the principle that water should be considered as a scarce, economic good. It is not sufficient to leave the implementation of this principle to national governments without having some kind of international protocol on the implementation, because unilateral implementation can be expected to be at the cost of the countries moving ahead [74]. The competitiveness of the producers of water-intensive products in a country that one-sidedly implements a stringent water pricing policy will be affected, and this, together with the natural resistance of domestic consumers to higher prices of local products, will reduce the feasibility of a unilateral implementation of a rigorous water pricing strategy.

If an international protocol on full-cost water pricing were in place, this would have a positive effect on a number of the global water issues described in this paper. The protocol would primarily contribute to resource use efficiency, because proper marginal-cost pricing is a precondition to arrive at efficient allocation schemes. It would further contribute to the sustainable use of the world's water resources, because water scarcity would be translated into a scarcity rent and thus affect consumer decisions, even if those consumers live at a great distance from the production site. Proper water pricing would shed new light upon the economic feasibility of plans for large-scale inter-basin transfers, since it would force negative externalities and opportunity costs to be taken into account. Finally, a water-pricing protocol would contribute to fairness, by making producers and consumers pay for their contribution to the depletion and pollution of water. Full-cost water pricing should be combined with a minimum water right, in order to prevent poor people not being able to obtain their basic needs.

\subsection{A Pollution Tax and International Nutrient Housekeeping}

Another global arrangement may be needed to prevent water problems in the waste stage of product. (An international water-pricing protocol would cover the costs of water use and pollution in the production stage of products, but it would not cover costs in the waste stage). This arrangement could have the form of a 'pollution tax' or 'disposal tax' on goods that will cause water pollution in their waste stage. The tax should be paid by the consumer; the money collected could be used to promote pollution prevention and control. The tax would be supposed to work as an incentive for producers to adapt production processes, and for consumers to change consumption behavior. This sort of arrangement can be implemented unilaterally within one nation state. However, it will be difficult to combat the type of pollution that relates to product trade in the global economy through unilateral pollution taxes. To counter processes of soil depletion and eutrophication that are linked to international trade in food and feed, as described in Section 2.4, a global arrangement is essential. Such a global arrangement would combine measures to combat soil depletion in the exporting country with measures to combat eutrophication in the importing country. In fact there are only two sustainable solutions: Either stop the one-directional trade flow of nutrients, or bring back the nutrients that come in the form of food or feed as fertilizer or other forms of food or feed. Both solutions impact on the economy of the trading nations. While international trade is currently governed by the requirement (at least over the long term) of closing national trade balances, another restriction should be imposed in 
the shape of a requirement that national nutrient trade balances should also close. This principle has been introduced and implemented in the Netherlands at farm level, but introduction at national level would be more complex and would require international cooperation.

\subsection{Water-labeling of Water-intensive Products or Water-certification of Industries}

A third possible global arrangement could be a water label for water-intensive products, comparable to the label of the Forest Stewardship Council (FSC) for wood products or the label of the Marine Stewardship Council (MSC) for marine products. Such a label would make consumers aware of the actual, but so far hidden, link between a consumer product and the impacts on water systems that occur during production. A water label should give a guarantee to the consumer that the product was produced under some clearly defined conditions. The label could be introduced first for a few commodities that usually have great impact on water systems, such as rice, cotton and sugar cane. Given the global character of the rice, cotton and sugar markets, international cooperation in setting the labeling criteria, and in the practical application of the water label, is a precondition. Consideration could be given to integrating the water label within a broader environmental label, but this would probably create new bottlenecks for implementation, so that a first step could be to agree on a separate water label.

An alternative to consumer-oriented water labeling of products could be the introduction of producer-oriented water certification of industries or retailers. In such an arrangement, industries or retailers can obtain a water certificate when their own activities and the activities of their suppliers meet certain specified criteria with respect to efficient, sustainable and fair water use. Obtaining a water certificate could be made either voluntary (for example as a start) or compulsory (later on). Water use is not restricted to the processes within industries; the production of the resources that are inputs to industries also requires water, for instance in agriculture and mining. Therefore, retailers and industries should use their power to influence agents earlier in the production chain to change their water use in a sustainable direction. According to Hall [94] this is possible for so-called channel leaders, which have the technical competencies and can trigger chain dynamics. A number of big international companies, united in the World Business Council for Sustainable Development, have expressed their expectation that 'water footprint reporting' may soon become common practice and even obligatory for businesses in various countries [95].

A number of recent initiatives have been taken in the fields of water labeling, certification and reporting, including the Alliance for Water Stewardship (http://www.allianceforwaterstewardship.org), the Water Stewardship Programme of the European Water Partnership (http://www.ewp.eu), the ISO Water Footprint working group (http://www.iso.org), and the Water Disclosure Project (http://www.cdproject.net/water-disclosure). The Water Footprint Network has formulated the global standard for water footprint assessment [96], so that, whatever labels, certificates or reporting schemes are developed, a commonly shared framework of definitions and calculation is applied. Early in 2011, the Water Footprint Network will publish a new version of the global standard for water footprint assessment [106]. 


\subsection{Minimum Water Rights}

Fairness and sustainability in water use require the establishment of both minimum water rights and maximum allowable levels of water use. The latter has received little attention from the international community and will be discussed in the next section. The issue of minimum water rights has had more consideration [35,97,98]. At international level, efforts have been made to have access to clean drinking water accepted as a human right. The Universal Declaration of Human Rights from 1948 does not mention access to water as a human right, but the first paragraph of article 25 reads: 'Everyone has the right to a standard of living adequate for the health and well-being of himself and of his family, including food, clothing, housing and medical care and necessary social services, ...'. With a little good will, one could say that the right to a certain minimum of water is thereby implicitly established. A step towards the more explicit formulation of the right to water was made in 1976 with Article 12 of the International Covenant on Economic, Social, and Cultural Rights, which acknowledges 'the right of everyone to the enjoyment of the highest attainable standard of physical and mental health'. In 2000 the Committee on Economic, Social and Cultural Rights of the United Nations (General Comment No. 14) accepted a supplement to this covenant which states that 'the right to health embraces a wide range of socio-economic factors that promote conditions in which people can lead a healthy life, and extends to the underlying determinants of health, such as food and nutrition, housing, access to safe and potable water and adequate sanitation, safe and healthy working conditions, and a healthy environment'. In 2002 the same committee specified the right to water in General Comment No. 15: 'The human right to water entitles everyone to sufficient, safe, acceptable, physically accessible and affordable water for personal and domestic uses. An adequate amount of safe water is necessary to prevent death from dehydration, to reduce the risk of water-related disease and to provide for consumption, cooking, personal and domestic hygienic requirements.' In July 2010, the General Assembly of the United Nations adopted a resolution that recognized the right to drinking water and sanitation as a human right. Then, in September, the Human Rights Council affirmed the decision, explaining that the right to water and sanitation was derived from the right to an adequate standard of living, which is contained in several existing human rights treaties, including the International Covenant on Economic, Social and Cultural Rights and the Convention on the Rights of the Child.

The human right to water has thus formally been established, but there are no enforcement mechanisms. Besides, the right specifically refers to water for basic needs in domestic use, not to water for food. Food itself as a human right had already been established explicitly in Article 25 of the Universal Declaration of Human Rights. Although one cannot deny that the right to food translates into a certain volume of water required to produce the food, the right to food has never been translated into a 'right to water for food'. On the level of the individual this is also not useful, because that would wrongly presuppose that every individual produces his or her own food. However, the right to food implies that every individual has a sort of 'claim' on a certain volume of the world's water resources that is required to produce the amount of food that he or she is entitled to according to the existing right to food. Given the uneven distribution of water across the world, an important question is: How do the existing human rights to water and food translate into a moral obligation of communities that have abundant water resources at their disposal towards communities with severely limited water resources? One of the concrete steps taken by the international community has been the formulation of 
the Millennium Development Goals during the UN Millennium Summit in New York in 2000. Definite targets are for instance to reduce by half the proportion of people who suffer from hunger and also to reduce by half the proportion of people without sustainable access to safe drinking water (both targets referring to the period 1990-2015). The weak point of the Millennium Development Goals is that they lack a clear course of action and a mechanism for enforcement. As a result, there is no guarantee that the good intentions will be realized.

\subsection{Water Footprint Quotas}

The issues of fair water allocation and sustainable water use demand some global arrangement about maximum allowable levels of water use [59,74,99,100]. As argued in Section 3.2, the limited availability of freshwater in the world puts a maximum on the human global water footprint. Maximum allowable water footprints would need to be defined per river basin and period of the year. The maximum allowable water footprint in river basin in a specific period of the year obviously depends on the natural water availability and environmental water needs in that basin in that period of the year. The maximum allowable annual water footprint at global level is the sum of the maximum allowable water footprints in specific river basins in specific periods of the year. The question for the global community is how the global maximum water footprint can be transferred to the national or even the individual level. Or in other words: What is each nation's and each individual's 'reasonable' share of the globe's water resources? An international protocol on this issue would be comparable to the Kyoto Protocol on the emission of greenhouse gases (drafted in 1997, effective since 2005), which is based on the understanding that, to prevent human-induced climate change, there is a ceiling on the maximum volume of greenhouse gas emissions from human activities that can be accommodated by the global system. The fact that it is not known exactly what this ceiling is has apparently not held the international community back in setting political targets with respect to greenhouse gas emission reductions. The same would have to happen if the international community were willing to set targets with respect to maximum water footprints, because here also the precise ceiling on water use is unknown, as explained earlier in this paper. In the case of the Kyoto Protocol, the maximum allowable emission permits have been issued in the form of tradable emission permits (quotas, credits). In the case of a protocol on water use, this could be done in a similar form of tradable water footprint quotas, but the tradability is not a necessity and probably highly problematic, since water is a global resource but manifests itself locally, which means that water footprint units are not exchangeable like emission units. In the case of greenhouse gas emissions there is one global ceiling; it does not matter where the emissions take place. In the case of the water footprint, there is also a global ceiling, but this is the sum of ceilings specified by river basin and period of the year.

The global water footprint quota would be allocated to nations, not according to natural water endowments but according to the philosophy of fair shares, where a nation's fair water footprint share would need to be negotiated. As a starting point for negotiating a fair water footprint share per country, one could simply take the national population as fraction of the world population times the aggregated global freshwater availability minus aggregated global environmental water needs. Each individual national government would have the obligation to move producers and consumers towards a production and consumption pattern that fits within the national quota. For this purpose governments 
can use the classic instruments like subsidies, taxes, regulation, awareness raising and making contracts with businesses. A nation with a certain annual water footprint quota would not be allowed to have a larger water footprint than prescribed by the quota; in addition, the water footprint should have a spatial and temporal distribution that fits within the spatial and temporal pattern of maximum allowable water footprints.

\subsection{Implementing the Water-Neutral Concept}

Various activities require a lot of water. The idea of the water-neutral (or water-offset) concept is to stimulate individuals and corporations that undertake water-consuming activities to make their activity 'water neutral' by investing at the same time in water conservation measures or in water supply to the poor. In other words, water-neutral consumption or production offsets the adverse environmental and social consequences of the consumption - or production-related water footprint. The water-neutral concept was conceived by Pancho Ndebele at the 2002 Johannesburg World Summit for Sustainable Development (WSSD) and scientifically elaborated by Hoekstra [101]. The idea at the time of the Summit was to quantify the water consumed during the conference by delegates and translating this into real money. Delegates, corporations, civil society groups were encouraged to make the summit water neutral by purchasing water-neutral certificates to offset their water consumption during the ten-day summit, with the offset investment being earmarked for the installation of pumps to water needy communities in South Africa and water conservation initiatives. As a follow-up, an initiative has been taken by the Water Neutral Foundation in South Africa to implement the water-neutral concept in the tourist sector, as the central element of an awareness and conservation campaign targeted at individuals, corporations and other organizations keen to contribute towards quenching the thirst of Africans that currently do not have access to clean drinking water. In 2007, the Coca-Cola Company made a pledge to become water neutral in its businesses, a move that did not remain unnoticed by the press [102]. In the same year, the U.K. Housing Ministry released official details on the expansive redevelopment project 'Thames Gateway' that would be water-neutral, in this context meaning that the region will not require the use of additional water despite the plethora of new homes being built and people moving in [103].

The water-neutral or water-offset concept is similar to the carbon-neutral or carbon-offset concept as has been developed in response to the challenge of taking climate change counter-measures. The principle of the concept is that a person pays a justified amount of money for the water footprint that he/she presses on the global water resources. It can be an instrument to raise awareness and generate funds for the sustainable and fair use of freshwater resources. The water-neutral concept offers a great opportunity to translate water footprint impacts into action to mitigate those impacts within both communities and businesses. However, there are a number of important questions that need to be answered clearly as a precondition for the success of the water-neutral concept. These are for example: When can an activity be called water neutral? How to define system boundaries? How much reduction of a water footprint can reasonably be expected? What is an appropriate water-offset price? What type of efforts count as an offset?

There is a need for scientific rigor in accounting methods and for clear (negotiated) guidelines on the conditions that have to be met before one can speak about water neutrality [101]. Undoubtedly 
there will be a great market for water-neutrality and water-offsetting, comparable to the market for carbon neutrality and offsetting, but the extent to which this market will become effective in contributing to a more efficient, sustainable and equitable use of the globe's water resources will depend on the rules of the market. Without agreed definitions and guidelines on what is water neutrality, the term is most likely to end up as a catchword for raising funds for charity projects in the water sector. In that context, the term can also fulfill a useful function, but it would be 'water neutrality' in its weakest form. It can become a strong concept only when claims towards water-neutrality can be measured against clear standards.

\subsection{The Way Forward}

The above exploration of possible global arrangements in order to contribute to good water governance is definitely not exhaustive. Not mentioned, for instance, are the necessary global arrangements to mitigate climate change (to be seen in addition to local and regional arrangements for adaptation), but the global community has taken some steps here already, as witness the work of the Intergovernmental Panel on Climate Change and the Kyoto Protocol. Also not mentioned, is the need for an international business code for multinationals in the water sector, to guarantee that in cases where governmental control is ineffective, this is compensated for by international regulations. Such regulations could provide rules about supply obligations and dedicated pricing structures for the poor who cannot afford normal tariffs, and would need to include enforcement arrangements.

The various alternative global arrangements discussed above have in common that they aim to create some sort of global regime for freshwater use in order to promote water use efficiency, ensure sustainable water use, and encourage equitable sharing of the limited freshwater resources. In proposing such arrangements, I have taken a very optimistic view with regard to the feasibility of implementing such arrangements and with regards to the associated transaction costs. This approach may suit well within the view of liberal institutionalism, the school that believes in the potential for international cooperation that goes beyond the self-interest of states. This is opposed to the tradition of political realism, which pictures world politics to be a struggle for power between states, in which every state tries to maximize its own interests. As a result, the political feasibility of the proposed arrangements can be contested from a realist's point of view.

It is impossible to predict to which extent the various possible global arrangements discussed above will be implemented within the decades ahead of us. The contentious issues in the realm of implementation will be at least as prominent as those arising in the case of climate change mitigation. The path towards, and the implementation of, the Kyoto protocol and the more recent Copenhagen negotiations both provide arguments to be positive about the potential of international cooperation for the benefit of the global society and critical points that illustrate the difficulties, costs and ineffectiveness.

\section{Discussion}

The fact that oil is generally seen as a global resource and water as a local resource can be understood but not justified. The oil of the Middle East is 'owned' by the countries in the Middle East to the same extent that the water in Brazil is 'owned' by Brazil. In that sense, both resources are local. 
At the same time, both oil in the Middle East and water in Brazil are critically relevant for the global community as a whole. In that sense, both resources are global. The countries in the Middle East export oil; Brazil exports water (in virtual form).

The argument for coordination at a global level as made in this paper seems to be at odds with the subsidiarity principle, nowadays widely accepted and promoted in the field of water governance. This principle means that water issues should be settled at the lowest community level possible. Whether this causes tension depends on how one interprets the subsidiarity principle. In this paper it has been argued that the issues discussed are truly global issues that cannot be solved at a lower community level than that of the global community, so there is no conflict with the subsidiarity principle. However, it is a fact that global arrangements in the area of water governance do definitely subtract from the mandates at lower community levels. Finding a balance between institutional arrangements at different levels of governance will indeed be a true challenge.

\section{References}

1. Foley, J.A.; DeFries, R.; Asner, G.P.; Barford, C.; Bonan, G.; Carpenter, S.R.; Chapin, F.S.; Coe, M.T.; Daily, G.C.; Gibbs, H.K.; Helkowski, J.H.; Holloway, T.; Howard, E.A.; Kucharik, C.J.; Monfreda, C.; Patz, J.A.; Prentice, I.C.; Ramankutty, N.; Snyder, P.K. Global consequences of land use. Science 2005, 309, 570-574.

2. Nicholson, S. Land surface processes and Sahel climate. Rev. Geophys. 2000, 38, 117-139.

3. Gallart, F.; Llorens, P. Catchment management under environmental change: Impact of land cover change on water resources. Water Int. 2003, 28, 334-340.

4. Mitchell, B. Integrated water resource management, institutional arrangements, and land-use planning. Environ. Plan. A 2005, 37, 1335-1352.

5. Terpstra, J.; Van Mazijk, A. Computer aided evaluation of planning scenarios to assess the impact of land-use changes on water balance. Phys. Chem. Earth B 2001, 26, 523-527.

6. Syvitski, J.P.M.; Vörösmarty, C.J.; Kettner, A.J.; Green, P. Impact of humans on the flux of terrestrial sediment to the global coastal system. Science 2005, 308, 376-380.

7. Kundzewicz, Z.W.; Mata, L.J.; Arnell, N.W.; Döll, P.; Kabat, P.; Jiménez, B.; Miller, K.A.; Oki, T.; Sen, Z.; Shiklomanov, I.A. Freshwater resources and their management. Climate Change 2007: Impacts, Adaptation and Vulnerability. In Contribution of Working Group II to the Fourth Assessment Report of the Intergovernmental Panel on Climate Change; Parry, M.L., Canziani, O.F., Palutikof, J.P., van der Linden, P.J., Hanson, C.E., Eds.; Cambridge University Press: Cambridge, UK, 2007; pp. 173-210.

8. Vörösmarty, C.J.; Green, P.; Salisbury, J.; Lammers, R.B. Global water resources: Vulnerability from climate change and population growth. Science 2000, 289, 284-288.

9. Duarte, R.; Sanchez-Choliz, J.; Bielsa, J. Water use in the Spanish economy: an input-output approach. Ecol. Econ. 2002, 43, 71-85.

10. Water for Life: Making It Happen; World Health Organization (WHO): Geneva, Switzerland, 2005.

11. Postel, S.L.; Daily, G.C.; Ehrlich, P.R. Human appropriation of renewable fresh water. Science 1996, 271, 785-788. 
12. Smakhtin, V.; Revenga, C.; Döll, P. A pilot global assessment of environmental water requirements and scarcity. Water Int. 2004, 29, 307-317.

13. Oki, T.; Kanae, S. Global hydrological cycles and world water resources. Science 2006, 313, 1068-1072.

14. Allan, J.A. The Middle East Water Question: Hydropolitics and the Global Economy; I.B. Tauris \& Co Ltd: London, UK, 2001.

15. Water Resources Sector Strategy: Strategic Directions for World Bank Engagement; World Bank: Washington, DC, USA, 2004.

16. Organisation for Economic Co-operation and Development (OECD). Emerging Risks in the 21st Century: An Agenda for Action; OECD: Paris, France, 2003.

17. World Meteorological Organization; the Cooperative Programme on Water and Climate; Japan Water Forum. Risk Management, Thematic Document; In 4th World Water Forum, Mexico City, Mexico, 16-22 March, 2006; World Meteorological Organization: Geneva, Switzerland, 2006.

18. Rogers, P.; Hall, A.W. Effective Water Governance; TEC Background Papers No. 7; Global Water Partnership: Stockholm, Sweden, 2003.

19. Liu, C.M.; Zheng, H.X. South-to-north water transfer schemes for China. Int. J. Water Resour. Dev. 2002, 18, 453-471.

20. Berkoff, J. China: The south-north water transfer project-is it justified? Water Policy 2003, 5, $1-28$.

21. Wu, X.F.; Liu, C.M.; Yang, G.L.; Fu, Q. Available quantity of transferable water and risk analysis: Western route project for south-to-north water transfer in China. Water Int. 2006, 31, 81-86.

22. Zhao, F.Z.; Liu, W.H.; Deng, H.B. The potential role of virtual water in solving water scarcity and food security problems in China. Int. J. Sustain. Dev. World Ecol. 2005, 12, 419-428.

23. Yang, R.J.; Liu, G.H.; Zhao, F.Z.; Fu, B. Eco-environmental benefit assessment of the western route in China's South-North Water Transfer Project. Int. J. Sustain. Dev. World Ecol. 2005, 12, 461-470.

24. Yang, H.; Zehnder, A.J.B. The south-north water transfer project in China: An analysis of water demand uncertainty and environmental objectives in decision making. Water Int. 2005, 30, 339-349.

25. Gupta, S.K.; Deshpande, R.D. Water for India in 2050: first-order assessment of available options. Curr. Sci.2004, 86, 1216-1224.

26. Jain, S.K.; Reddy, N.S.R.K.; Chaube, U.C. Analysis of a large inter-basin water transfer system in India. Hydrolog. Sci. J. 2005, 50, 125-137.

27. Verma, S.; Kampman, D.A.; Van der Zaag, P.; Hoekstra, A.Y. Going against the flow: A critical analysis of inter-state virtual water trade in the context of India's National River Linking Programme. Phys. Chem. Earth B 2009, 34, 261-269.

28. Basson, M.S. South African water transfer schemes and their impact on the southern African region. In Water Resource Use in the Zambezi Basin: Proceedings of a Workshop Held at Kasane, Botswana; Matiza, T., Crafter, S., Dale, P., Eds.; International Union for Conservation of Nature (IUCN): Gland, Switzerland, 1995; pp. 41-48. 
29. Nel, E.; Illgner, P. Tapping Lesotho's 'white gold'-Inter-basin water transfer in Southern Africa. Geography 2001, 86, 163-167.

30. Ballestero, E. Inter-basin water transfer public agreements: A decision approach to quantity and price. Water Resour. Manag. 2004, 18, 75-88.

31. Experiences with Inter Basin Water Transfers for Irrigation, Drainage and Flood Management, Revised Draft Report of the ICID Task Force on Inter Basin Water Transfers; International Commission on Irrigation and Drainage (ICID), New Delhi, India, 2006.

32. Gleick, P.H. Bottled and Sold: The Story behind Our Obsession with Bottled Water; Island Press: Washington, DC, USA, 2010.

33. Barlow, M.; Clarke, T. Blue Gold: The Battle against Corporate Theft of the World's Water; The New Press: New York, NY, USA, 2002.

34. Petrella, R. The Water Manifesto: Arguments for a World Water Contract; Zed Books: London, UK, 2001.

35. Gleick, P.H. The human right to water. Water Policy 1998, 1, 487-503.

36. Shiva, V. Water Wars: Privatization, Pollution, and Profit; South End Press: Cambridge, MA, USA, 2002.

37. Milly, P.C.D.; Wetherald, R.T.; Dunne, K.A.; Delworth, T.L. Increasing risk of great floods in a changing climate. Nature 2002, 415, 514-517.

38. Karl, T.R.; Trenberth, K.E. Modern global climate change. Science 2003, 302, 1719-1723.

39. Bellouin, N.; Boucher, O.; Haywood, J.; Reddy, M.S. Global estimate of aerosol direct radiative forcing from satellite measurements. Nature 2005, 438, 1138-1141.

40. Kalnay, E.; Cai, M. Impact of urbanization and land-use change on climate. Nature 2003, 423, 528-531.

41. Pielke, R.A. Land use and climate change. Science 2005, 310, 1625-1626.

42. Feddema, J.J.; Oleson, K.W.; Bonan, G.B.; Mearns, L.O.; Buja, L.E.; Meehl, G.A.; Washington, W.M. The importance of land-cover change in simulating future climates. Science 2005, 310, 1674-1678.

43. Savenije, H.H.G. New definitions for moisture recycling and the relationship with land-use changes in the Sahel. J. Hydrol. 1995, 167, 57-78.

44. Climate change 2007: The Physical Science Basis, Contribution of Working Group I to the Fourth Assessment Report of the IPCC; Solomon, S., Qin, D., Manning, M., Chen, Z., Marquis, M., Averyt, K.B., Tignor M., Miller, H.L., Eds.; Cambridge University Press: Cambridge, UK, 2007.

45. van den Hurk, B.; Klein, T.A.; Lenderink, G.; van Ulden, A.; van Oldenborgh, G.J.; Katsman, C.; van den Brink, H.; Keller, F.; Bessembinder, J.; Burgers, G.; Komen, G.; Hazeleger, W.; Drijfhout, S. KNMI Climate Change Scenarios 2006 for the Netherlands; KNMI Scientific Report WR 2006-01; Koninklijk Nederlands Meteorologisch Instituut (KNMI): De Bilt, The Netherlands, 2006.

46. Crutzen, P.; Komen, G.; Verbeek, K.; van Dorland, R.; Van Ulden, A. Veranderingen in het klimaat; KNMI: De Bilt, The Netherlands, 2005. 
47. Middelkoop, H.; Daamen, K.; Gellens, D.; Grabs, W.; Kwadijk, J.C.J.; Lang, H.; Parmet, B.W.A.H.; Schädler, B.; Schulla, J. Impact of climate change on hydrological regimes and water resources management in the Rhine Basin. Climatic Change 2001, 49, 105-128.

48. Grote, U.; Craswell, E.; Vlek, P. Nutrient flows in international trade: Ecology and policy issues. Environ. Sci. Policy 2005, 8, 439-451.

49. Sanchez, P.A. Soil fertility and hunger in Africa. Science 2002, 295, 2019-2020.

50. Stocking, M.A. Tropical soils and food security: The next 50 years. Science 2003, 302, 1356-1359.

51. McIsaac, G.F.; David, M.B.; Gertner, G.Z.; Goolsby, D.A. Eutrophication: Nitrate flux in the Mississippi river. Nature 2001, 414, 166-167.

52. Tilman, D.; Fargione, J.; Wolff, B.; D’Antonio, C.; Dobson, A.; Howarth, R.; Schindler, D.; Schlesinger, W.H.; Simberloff, D.; Swackhamer, D. Forecasting agriculturally driven global environmental change. Science 2001, 292, 281-284.

53. Meybeck, M.; Helmer, R. The quality of rivers: From pristine stage to global pollution. Palaeogeogr. Palaeoclimatol. 1989, 75, 283-309.

54. Meybeck, M. The global change of continental aquatic systems: dominant impacts of human activities. Water Sci. Technol. 2004, 49, 73-83.

55. Nriagu, J.O.; Pacyna, J.M. Quantitative assessment of worldwide contamination of air, water and soils by trace metals. Nature 1988, 333, 134-139.

56. Siebert, S.; Döll, P. Quantifying blue and green virtual water contents in global crop production as well as potential production losses without irrigation. J. Hydrol. 2010, 384, 198-207.

57. Mekonnen, M.M.; Hoekstra, A.Y. A global and high-resolution assessment of the green, blue and grey water footprint of wheat. Hydrol. Earth Syst. Sci. 2010, 14, 1259-1276.

58. Allan, J.A. Watersheds and problemsheds: Explaining the absence of armed conflict over water in the Middle East. Middle East Rev. Int. Aff. 1998, 2, 49-51.

59. Hoekstra, A.Y.; Chapagain, A.K. Globalization of Water: Sharing the Planet's Freshwater Resources; Blackwell Publishing: Oxford, UK, 2008.

60. Haddadin, M.J. Exogenous water: A conduit to globalization of water resources. In Virtual Water Trade: Proceedings of the International Expert Meeting on Virtual Water Trade; Value of Water Research Report Series No. 12; Hoekstra, A.Y., Ed.; Institute for Water Education of the United Nations Educational, Scientific and Cultural Organization (UNESCO-IHE): Delft, The Netherlands, 2003; pp. 159-169.

61. Chapagain, A.K.; Hoekstra, A.Y. Water Footprints of Nations; Value of Water Research Report Series No. 16; UNESCO-IHE: Delft, The Netherlands, 2004.

62. Zimmer, D.; Renault, D. Virtual water in food production and global trade: Review of methodological issues and preliminary results. In Virtual Water Trade: Proceedings of the International Expert Meeting on Virtual Water Trade; Value of Water Research Report Series No. 12; Hoekstra, A.Y., Ed.; UNESCO-IHE: Delft, The Netherlands, 2003; pp. 93-109.

63. Zehnder, A.J.B.; Yang, H.; Schertenleib, R. Water issues: The need for action at different levels. Aquat. Sci. 2003, 65, 1-20.

64. Wichelns, D. The policy relevance of virtual water can be enhanced by considering comparative advantages. Agr. Water Manage. 2004, 66, 49-63. 
65. Hoekstra, A.Y.; Hung, P.Q. Virtual Water Trade: A Quantification of Virtual Water Flows between Nations in Relation to International Crop Trade; Value of Water Research Report Series No. 11; UNESCO-IHE: Delft, The Netherlands, 2002.

66. Hoekstra, A.Y.; Hung, P.Q. Globalisation of water resources: International virtual water flows in relation to crop trade. Global Environ. Change 2005, 15, 45-56.

67. Oki, T.; Kanae, S. Virtual water trade and world water resources, Water Sci. Technol. 2004, 49, 203-209.

68. Chapagain, A.K.; Hoekstra, A.Y. The global component of freshwater demand and supply: An assessment of virtual water flows between nations as a result of trade in agricultural and industrial products. Water Int. 2008, 33, 19-32.

69. De Fraiture, C.; Cai, X.; Amarasinghe, U.; Rosegrant, M.; Molden, D. Does international Cereal Trade Save Water? The Impact of Virtual Water Trade on Global Water Use; Comprehensive Assessment Research Report 4; International Water Management Institute (IWMI): Colombo, Sri Lanka, 2004.

70. Yang, H.; Reichert, P.; Abbaspour, K.C.; Zehnder, A.J.B. A water resources threshold and its implications for food security. Environ. Sci. Technol. 2003, 37, 3048-3054.

71. Chapagain, A.K.; Hoekstra, A.Y.; Savenije, H.H.G. Water saving through international trade of agricultural products. Hydrol. Earth Syst. Sci. 2006, 10, 455-468.

72. Hoekstra, A.Y.; Chapagain, A.K. Water footprints of nations: Water use by people as a function of their consumption pattern. Water Resour. Manage. 2007, 21, 35-48.

73. Van Oel, P.R.; Mekonnen M.M.; Hoekstra, A.Y. The external water footprint of the Netherlands: Geographically-explicit quantification and impact assessment. Ecol. Econ. 2009, 69, 82-92.

74. Hoekstra, A.Y. The Relation between International Trade and Freshwater Scarcity; Working Paper ERSD-2010-05; World Trade Organization: Geneva, Switzerland, 2010. Available online: http://www.wto.org/english/res_e/reser_e/ersd201005_e.pdf (accessed on 5 July 2010).

75. Micklin, P.P. Desiccation of the Aral Sea: A water management disaster in the Soviet Union. Science 1988, 241, 1171-1176.

76. Chapagain, A.K.; Hoekstra, A.Y.; Savenije, H.H.G.; Gautam, R. The water footprint of cotton consumption: An assessment of the impact of worldwide consumption of cotton products on the water resources in the cotton producing countries. Ecol. Econ. 2006, 60, 186-203.

77. Aldaya, M.M.; Muñoz, G.; Hoekstra, A.Y. Water Footprint of Cotton, Wheat and Rice Production in Central Asia; Value of Water Research Report Series No. 41; UNESCO-IHE: Delft, The Netherlands, 2010.

78. Rogers, P.; De Silva, R.; Bhatia, R. Water is an economic good: How to use prices to promote equity, efficiency and sustainability. Water Policy 2002, 4, 1-17.

79. Unlocking the Water Potential of Agriculture; Food and Agriculture Organization (FAO): Rome, Italy, 2003.

80. Deng, X.P.; Shan, L.; Zhang, H.; Turner, N.C. Improving agricultural water use efficiency in arid and semiarid areas of China. Agr. Water Manage. 2006, 80, 23-40.

81. Wilson, C. Schools water efficiency and awareness project. Water SA 2004, 30, 641-642.

82. AQUASTAT Database; Food and Agriculture Organization (FAO): Rome, Italy, 2006. Available online: http://www.fao.org/nr/water/aquastat/main/index.stm (accessed on 5 July 2010). 
83. Beaumont, P. The quest for water efficiency-Restructuring of water use in the Middle East. Water Air Soil Pollut. 2000, 123, 551-564.

84. Yang, H.; Wang, L.; Abbapour; K.C.; Zehnder, A.J.B. Virtual water trade: an assessment of water use efficiency in the international food trade. Hydrol. Earth Syst. Sci. 2006, 10, 443-454.

85. World Health Statistics 2009; World Health Organization (WHO): Geneva, Switzerland, 2009.

86. United Nations Educational, Scientific, and Cultural Organization (UNESCO). Water for People, Water for Life; The United Nations World Water Development Report; UNESCO Publishing, Paris, France and Berghahn Books: New York, NY, New York, 2003.

87. UNESCO. Water, A Shared Responsibility; The United Nations World Water Development Report 2; UNESCO Publishing, Paris, France and Berghahn Books: New York, NY, USA, 2006.

88. UNESCO. Water in A Changing World; The United Nations World Water Development Report 3; UNESCO Publishing, Paris, France and Berghahn Books: New York, NY, USA, 2009.

89. Acreman, M.; Dunbar, M.J. Defining environmental river flow requirements—a review. Hydrol. Earth Syst. Sci. 2004, 8, 861-876.

90. Poff, N.L.; Richter, B.D.; Aarthington, A.H.; Bunn, S.E.; Naiman, R.J.; Kendy, E.; Acreman, M.; Apse, C.; Bledsoe, B.P.; Freeman, M.C.; Henriksen, J.; Jacobson, R.B.; Kennen, J.G.; Merritt, D.M.; O'Keeffe, J.H.; D.Olden, J.; Rogers, K.; Tharme, R.E.; Warner, A. The ecological limits of hydrologic alteration (ELOHA): A new framework for developing regional environmental flow standards. Freshwater Biol. 2009, 55, 147-170.

91. Review of World Water Resources by Country; Water Reports 23; FAO: Rome, Italy, 2003.

92. Liu, J.; Savenije, H.H.G. Food consumption patterns and their effect on water requirement in China. Hydrol. Earth Syst. Sci. 2008, 12, 887-898.

93. The Dublin Statement on Water and Sustainable Development. In Proceedings of the International Conference on Water and the Environment (ICWE); United Nations: Dublin, Ireland, 26-31, January, 1992.

94. Hall, J. Environmental supply chain dynamics. J. Clean. Prod. 2000, 8, 455-471.

95. Business in the World of Water: WBCSD Water Scenarios to 2025; World Business Council for Sustainable Development (WBCSD): Geneva, Switzerland, 2006.

96. Hoekstra, A.Y.; Chapagain, A.K.; Aldaya, M.M.; Mekonnen, M.M. Water Footprint Manual: State of the Art 2009; Water Footprint Network: Enschede, the Netherlands, 2009. Available online: http://www.waterfootprint.org/downloads/WaterFootprintManual2009.pdf (accessed on 5 July 2010).

97. The Right to Water; World Health Organization (WHO): Geneva, Switzerland, 2003.

98. Salman, S.M.A.; McInerney-Lankford, S. The Human Right to Water: Legal and Policy Dimensions; The World Bank: Washington, DC, USA, 2004.

99. Hoekstra, A.Y. The Global Dimension of Water Governance: Nine Reasons for Global Arrangements in Order to Cope with Local Water Problems; Value of Water Research Report Series No. 20; Institute for Water Education of the United Nations Educational, Scientific and Cultural Organization (UNESCO-IHE): Delft, The Netherlands, 2006. Available online: http://www.unesco-ihe.org/content/download/2714/27847/file/Report20-Global_Water_Governance.pdf (accessed on 5 July 2010).

100. Verkerk, M.P.; Hoekstra, A.Y.; Gerbens-Leenes, P.W. Global Water Governance: Conceptual Design of Global Institutional Arrangements; Value of Water Research Report Series No. 26; 
UNESCO-IHE: Delft, The Netherlands, 2008. Available online: http://www.unescoihe.org/ content/download/2720/27865/file/Report26-Verkerk-et-al2008GlobalWaterGovernance.pdf (accessed on 5 July 2010).

101. Hoekstra, A.Y. Water Neutral: Reducing and Offsetting the Impacts of Water Footprints; Value of Water Research Report Series No. 28; UNESCO-IHE: Delft, The Netherlands, 2008. Available online: http://www.waterfootprint.org/Reports/Report28-WaterNeutral.pdf (accessed on 5 July 2010).

102. Lewis, L. World Economic Forum: Is "Water Neutral" the Real Thing? Times Online, 25 June 2007. Available online: http://timesonline.typepad.com/urban_dirt/2007/06/world-economi-1.html (accessed on 5 July 2010).

103. Towards Water Neutrality in the Thames Gateway, Summary Report; Science Report SC060100/SR3; Environment Agency: Bristol, UK, 2007.

104. Lenzen, M.; Murray, J.; Sack, F.; Wiedmann, T. Shared producer and consumer responsibilityTheory and practice. Ecol. Econ. 2007, 61, 27-42.

105. Rodrigues, J.; Domingos, T. Consumer and producer environmental responsibility: Comparing two approaches. Ecol. Econ. 2008, 66, 533-546.

106. Hoekstra, A.Y.; Chapagain, A.K.; Aldaya, M.M.; Mekonnen, M.M. The Water Footprint Assessment Manual: Setting the Global Standard; Earthscan: London, UK, 2011.

(C) 2010 by the authors; licensee MDPI, Basel, Switzerland. This article is an open access article distributed under the terms and conditions of the Creative Commons Attribution license (http://creativecommons.org/licenses/by/3.0/). 